\title{
Community involvement and military heritage conservation: a case study of the demolition of the Antwerp sixteenth-century fortifications
}

\author{
J. Dobbels \& I. Bertels \\ Vrije Universiteit Brussels, Belgium
}

\begin{abstract}
This paper focuses on the case study of the nineteenth-century demolition of the sixteenth-century Antwerp fortifications (Belgium), more specifically on the various actors and motives behind the nineteenth-century debate and quest for both the demolition and preservation of this military heritage. The community involvement, including the various actors, their motives and impact of urban action groups on the nineteenth-century conservation debate will be reconstructed. An evaluation of the success of action groups if often based on immediate success (e.g. demolition or protection of heritage) or their life span. One has to question whether such an approach does not underestimate the possible impact of action groups that intensively influenced the political decision-making for a brief period? Therefore within this paper we will examine if other parameters like individual and sociological aspects are relevant to study action groups in a historical perspective, which mechanisms these actions groups used to influence the lively conservation debates and practices and how the authorities and public reacted on it.

Keywords: community involvement, urban action groups, contentious politics, military heritage, monument conservation, material preservation, iconographic preservation.
\end{abstract}

\section{Introduction}

Until recently the status of military heritage remained ambiguous. Both in the fields of (historical) heritage research and heritage policies, military architecture gained little attention. There is however a growing interest in the preservation of military heritage all over Europe. The establishment of an International Scientific 
Committee on Fortifications and Military Heritage by ICOMOS in 2005 is a case in point [1]. This paper tends to make a valuable contribution to military heritage research by focusing on the case study of the nineteenth-century demolition of the sixteenth-century Antwerp fortifications. The increasing interest in the preservation of military heritage makes that the construction, later evolution and deconstruction processes are already well known [2]. The construction of the sixteenth-century enceinte and the later erection of the citadel - seen as a symbol of Spanish oppression - are intensively studied. Furthermore the nineteenthcentury plea for their destruction as well as the impressive preservation campaign are popular themes in urban historical research [3]. As such this forms an interesting starting point for further research on the various actors and motives behind the nineteenth-century debate and quest for the preservation of this military heritage. This paper focuses on the role of community involvement with the demolition and preservation campaign for the Antwerp fortifications and will shed light on the personal actors, the 'urban action groups' and their objectives. Current historiography is mostly focussing on national discourses and international evolutions when studying the evolution of urban development and heritage conservation [4]. The local level deserves however also attention in this field of study. Furthermore, an evaluation of the success of action groups is too often based on their life span and immediate success (e.g. realisation or blocking of urban projects) [5]. But one has to question whether such an approach does not underestimate the possible impact of individual pioneers and petitioners that intensively influenced the political decision-making on monument conservation for a brief period? Therefore this paper will explore if other parameters like individual and sociological aspects are relevant to study these petitioners and 'action groups' in a historical perspective, which mechanisms these actions groups used and how the authorities and public reacted on it [6].

\section{Community involvement in contentious politics}

The term 'community involvement' generates a broad field of connotations. Research on the community involvement with the nineteenth-century preservation campaign for the Antwerp fortifications, therefore raises several questions. Which level of community involvement did this campaign contain? Did the whole community stood by the preservation idea? Or were there dissenting votes? What was the background (e.g. political, cultural, social background) of the individual petitioners? What moved these activists to plead for the preservation of the fortifications? Which mechanisms or 'repertoires of contention' did they use to influence the conservation debates and practices? Should this campaign be seen as the result of one 'action group' or as the preservation call of different individual petitioners? Did the campaign have an impact on the urban policy making on monument conservation?

Community involvement - the role and impact of participation in urban policy making - is a popular theme in urban sociological and political research. It is closely connected with concepts as social movements and urban action groups. In order to avoid the conceptual quagmire around these concepts, we will 
use the concept of 'contentious politics' in this paper. The term refers to 'episodic, public, collective interaction among makers of claims and their objects when (a) at least one government is a claimant, an object of claims, or a party to the claims and (b) the claims would, if realized, affect the interests of at least one of the claimants' [7]. Contentious politics can be divided into two broad categories: contained and transgressive contention. Contained - or institutional contention refers to cases of contention in which all parties are previously established actors employing eminent means of claim making. Transgressive - or unconventional - contention concerns collective interaction when at least some parties to the conflict are newly self-identified political actors and some employ innovative collective action [8]. The preservation campaign for the Antwerp fortifications was initiated and supported by several (politically not active) individuals and organisations as well as by institutionalised organisations. This paper will therefore combine both the concepts of transgressive and contained contention, as these subcategories are clearly strongly interwoven. The constituent parts of the concept 'contentious politics' - development, mobilization and 'repertoires of contention' - will be studied for the case study. Which threats and opportunities (re)moulded the development of this preservation campaign? Besides the immediate cause, other sociological aspects will be studied. These aspects involve political variables (e.g. the local government's perspectives on participation) and variables that influence whether the citizen participates or not (e.g. whether or not there is an extended society). The mobilizing structures will be studied because aspiring activists must either create an organizational vehicle or utilize an existing one and transform it into an instrument of contention to mobilize a participation group. By studying this group level on the one hand and individual participation on the other hand, this paper aims to establish a balanced and comparative view on the protest against the demolition of the Antwerp fortifications. The individual participation of the different actors will be studied with a biographical and prosopographical approach and a focus on individual aspects. These aspects include gender, age, level of education, professional profile; political, social and cultural profile. This approach was developed by Dezeure and De Rynck to research contemporary urban participation within sociological research and political science [9]. It will be applied (and adjusted if necessary) on the historical research of community involvement to depict the background of all participants and the interrelatedness within the participation group. Afterwards, the success of the community involvement with the Antwerp monument conservation policy will be studied. Scholars are still struggling to measure the impact of various participation and actions groups on policies for urban renewal and heritage conservation [10]. Their success is too often evaluated on their life span or on immediate success. In order to avoid undervaluing groups with a short life span that intensively influenced the political decision making on monument conservation, this paper will also take into account the media attention they received within a variety of communication possibilities and the reactions of the authorities and the public. The media attention contains mentions, articles, interviews, etc. published in the periodicals of the participation groups as well as in the broader press. The 
broadening of this evaluation system of participation groups allows a more thorough assessment of participation groups and community involvement.

\section{Antwerp fortifications: From unique large-scale enceinte till unwished-for urban restriction}

\subsection{Building process}

The sixteenth-century demographic growth reflects Antwerp's position as an international economic trade centre. In the first half of this golden age the population doubled from about 47,000 inhabitants (1496) to just over 100,000 (1568). The metropolis expressed its booming economic activities through the construction of new fortifications (1542-1553) designed by the Italian engineer Donato Boni de Pellizuoli. This large-scale enceinte, including nine bastions and five monumental entrance gates, was unseen in Europe [11]. Due to practicability, components of the earlier medieval city walls and gates, e.g. considerable elements of the Emperor's Gate, were incorporated.

.....In 1567, when the Dutch War of Independence started, the Spanish authorities erected a pentagonal citadel at Antwerp to control the rebellious city. This military stronghold was connected with the city walls at the Emperor's Gate. The Spanish fortress was seen as a symbol of foreign oppression and formed a thorn in the flesh of the Antwerp inhabitants The nineteenth-century economic revival caused an enormous demographic growth. Antwerp's position as the fourth biggest world port went hand in hand with the increase in population from 50,973 inhabitants (1784) over 88,487 (1846) till 302,058 inhabitants (1900), which made a new urban expansion essential [12]. Furthermore the sixteenth-century enceinte didn't meet the new military needs anymore. In 1859, Antwerp was transformed into Belgium's réduit national military stronghold where in time of war the Belgian army and government could take refuge while awaiting allied reinforcements - and new, larger fortifications where constructed (1859-1864). The Brialmont fortifications, named after the captain of the Belgian army Henri Alexis Brialmont, were a Grand Enceinte with an outer string of eight detached forts [13] [Figure 1].

.....In 1859 the Antwerp municipality reacquired ownership of the sixteenthcentury fortifications from the Belgian Army and argued for its complete dismantlement. The loss of its military function was not their only argument. Hygienic, public security and economic arguments were also used in the debate in favour of the demolition. In the council meeting of 6 August 1864, the 'deplorable insalubrity of the moats of the fortifications at the Kipdorp Gate' was denounced [14]. Since Antwerp's sewer system was not yet fully developed, the moats surrounding the walls were used as public dumping sites. Given the large number of children who fell into the moats, public security was another argument. However, the decisive factor was the economic development. All urban transport had to pass through the city gates with limited traffic capacity. In addition, entrepreneurs stated that the fortifications were a waste of valuable building lots. Their 'most vivid wish [15] to see our old ramparts pulled down' 


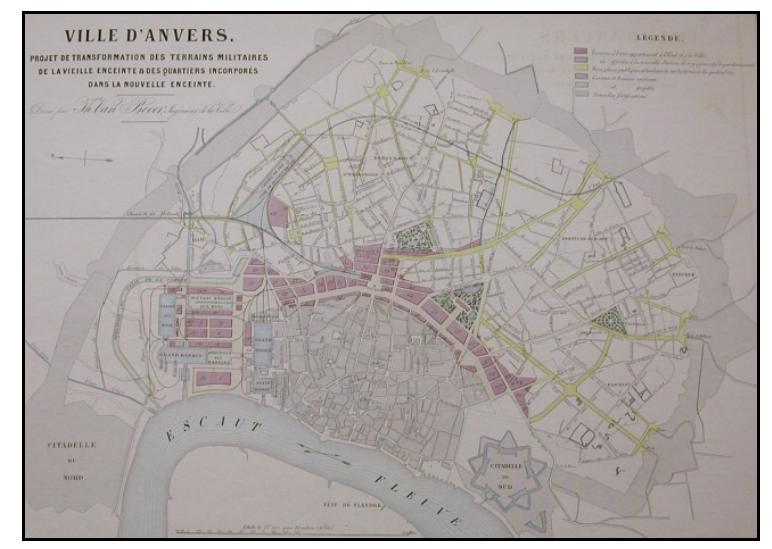

Figure 1: Theodoor Van Bever, urban expansion plan, 1863. (Royal Army Museum Brussels).

was seen as the only solution to Antwerp's need for urban and economic development [15].

\subsection{Preservation campaign}

The nineteenth-century plea for the demolition of the fortifications was countered by the preservation quest of this impressive architectural legacy. The preservation campaign was initiated by the painter Henri Leys (1815-1869) and the city archivist Pieter Génard (1830-1899). On 8 September 1864, they asked the Antwerp municipality to preserve the Emperor's Gate from demolition [16]. Their plea for preservation gained support from the Royal Commission for Monuments (Koninklijke Commissie voor Monumenten) - the national commission for advise on monument preservation founded in 1835 - and other architectural, artistic, and historical societies. This proved a vain attempt as the municipality of Antwerp voted the demolition of the fortifications in 1865. From 1866 on, the ramparts and entrance gates no longer determined the Antwerp townscape.

\subsubsection{Nineteenth-century 'paradoxical' approach of the past}

What was the immediate cause of this preservation plea? The urban expansion plan, created in 1863 by city engineer Theodoor Van Bever (1821-1875), planned the demolition of the sixteenth-century fortifications and its monumental entrance gates in order to accommodate Antwerp's need for urban and economic development. This illustrates the nineteenth-century 'paradoxical' approach of the past: demolishing and nevertheless preserving [17]. On the one hand, as a result of enormous infrastructure works, the old European town centres were (partly) demolished. On the other hand there arose a conservative vision that pleaded for town renewal with respect for historical heritage. This preservation idea was very vivid in the second half of the nineteenth century in Belgium. There was a fast institutionalization of monument conservation that started 
through the creation of the Royal Commission for Monuments in 1835 and was followed in 1861 by the development of the Provincial Commissions for Monuments (Provinciale Commissies voor Monumenten) [18]. The Antwerp Provincial Commission for Monuments was, in comparison with other provincial committees, very active. The local government's perspective on participation (on monument conservation practices) was influenced by these commissions. The Antwerp municipality accepted their advice on monument conservation matters but kept in mind that this had no obligatory effect and always put their own interests first. The real 'participation level' of these committees was thus extremely small. Nevertheless cultural organisations and commissions boosted and attracted more and more members. In this period of increasing interest in and institutionalisation of monument conservation, there was bound to arise a dissenting vote against the demolition of the Antwerp fortifications.

\subsubsection{Individual aspects of the key figures}

Due to the wide range of organisations and persons involved in the preservation campaign, this case study forms a complex example of contentious politics. When studying its development, a number of key figures attract attention. Leo de Burbure (1812-1889) and François Durlet (1816-1867), together with Henri Leys and Pieter Génard, can be conceived as pioneers due to their individual engagement in the preservation debate. Their cultural commitment for music, arts, archaeology, history and monument preservation was a clearly common feature that laid the foundation of the preservation campaign. An analysis of individual aspects as their gender, age, level of education, professional profile; political, cultural and social profile offers relevant insight in to the background of these participants and their functions in the participation group.

These key figures, all male, were centred in two age categories. Génard and Durlet were respectively 30 and 34 years old in 1864 where de Burbure and Leys had respectively an age of 52 and 49 years [19]. Their professional and cultural profiles bear a lot of resemblances: they were engaged in artistically-minded and archaeological circles. Génard was the city archivist, de Burbure catalogued the archives of the Antwerp Our Lady Cathedral, Leys was a famous painter and Durlet was an architect. These main occupation were supplemented with other professional activities (e.g. Durlet was also a teacher at the Antwerp Academy) and memberships of a wide range of (the executive committees of) cultural organisations and commissions. In contrast with the professional and cultural resemblances, there were some differences in their social background. The Burbure and Leys were of noble birth (respectively knight and baron) while Génard was a self-made man. Durlet's social background remains unknown. Their level of education also varies from Doctor of Law (de Burbure) over studies in Architecture and Sculpture (Durlet) and studies in painting (Leys). We are in a state of uncertainty on Génard's education. He already started working at the age of fourteen but counterbalanced this with being self-educated. As to their political activities, a lot of questions also remain unanswered. Although his biography doesn't contain any mentioning of membership of political parties, it is possible that Génard was a member of the catholic party. Leys' political 
background is even harder to reconstruct. While one biographer claims that "Leys' poetical mind rose above any political parties", another biographer states his membership of the Antwerp municipality. It seems that Durlet and de Burbure were politically inactive.

\subsubsection{Development of a wide-spread preservation campaign}

The mobilizing structures of this group are relatively easily reconstructed. The four key figures were all members of the Antwerp Provincial Commission for Monuments since its formation in 1861. They used this 'organizational vehicle' to mobilize a participation group. Firstly, they informed the Royal Commission for Monuments on the subject of the demolition, as was expected from them. Via their membership of other commissions, associations, executive committees of periodicals, etc. a wide range of organisations became acquainted with the debate on the demolition of the fortifications. The large majority of these associations supported the preservation idea explicitly. The Commission for Epitaphs and Commemorative Texts (Commissie van Graf-en Gedenkschriften) is a case in point. This association, which was responsible for the inventory and publication of Antwerp epitaphs, backed up the preservation idea by addressing it to the municipality [20]. Pieter Génard, the secretary and pivot of the organisation, certainly played a part in this, together with other members Leo de Burbure and Henri Leys. The support of the Association for Archaeology in Belgium (Académie d'Arcéologie de Belgique) and the periodical De Vlaemsche School was obtained in a similar way. For Génard, Leys and de Burbure were also members of these associations which made their connection with the preservation campaign almost self-evident [21]. The support of the Association of Antwerp Architects (Société des Architectes d'Anvers) proves that not only the membership of the key figures led to support. For none of the key figures was a member of this association, that openly acted from a preservation kind of view when contacting the municipality on the subject. The opposite hypothesis also holds water: not every association that counted Génard, Leys, de Burbure or Durlet among its members, supported openly the idea of preserving the Emperor's and Kipdorp Gate. The Belgian Royal Academy of Art (Académie Royal de beaux-arts) and the Commission of the Antwerp Archaeological Museum (Bestuurlijke Commissie van het Antwerpse Museum van Oudheden) are good examples. The group that reacted against the demolition plan was clearly heterogeneous.

\subsubsection{Selection of military architecture}

Which main objectives did they try to accomplish? From the beginning on, they pled for the preservation of two monumental entrance gates: the Emperor's Gate or the Berchemse Gate and the Kipdorp Gate or the Borgerhoutse Gate. [Figure 2(a) and (b)] A seventeenth-century guardhouse, next to the Emperor's Gate, and the Blue Tower also got their support for preservation. The preservation campaign clearly never included the other entrance gates or the fortifications as a whole. It can be seen as a resolute attempt to preserve the two most monumental components of this military architectural patrimony. The preservation group 


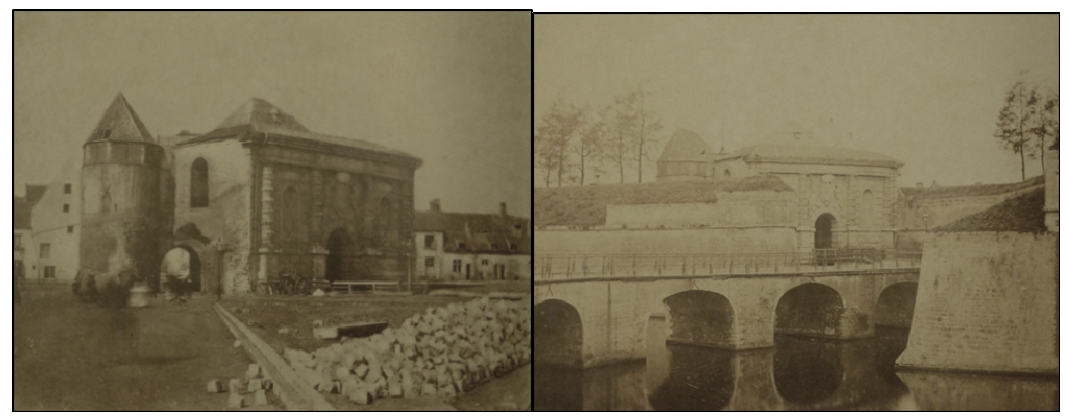

(a)

(b)

Figure 2: (a) The Emperor's Gate, Florent Joostens, 1865 and (b) the Kipdorp Gate, Florent Joostens, ca. 1863-1864.

aimed to achieve four goals. First of all, they demanded the preservation of the Emperor's and Kipdorp Gate. They also pled for the temporarily preservation of the fourteenth-century gate (situated next to the Kipdorp Gate). This would make it possible to study this piece of military architecture and decide whether or not it should be preserved. Thirdly, they deemed it fit to study similar (foreign) fortification demolitions on the subject of dismantlement of the ramparts without (severely) damaging the entrance gates. Finally, the urban expansion plan of Van Bever had to be adjusted in order to create a big square in front of the two entrance gates to show their monumentality. The preservation group kept these goals in view, even after the municipality decided on 3 June 1865 to demolish the complete fortifications. In fact, when there was a growing body of opinion that (one of) the gates could be demolished and reconstructed elsewhere, the preservation group kept their ground in pleading for preservation in situ. For after investigating the materials of the entrance gates, they judged a reconstruction inapplicable. When the material preservation of the entrance gates was no longer an option, the group took the initiative to guarantee the gates' iconographic preservation by demanding the production of architectural designs and photographs.

\subsubsection{Repertoires of contention}

Which range of mechanisms or 'repertoires of contention' did they use to influence the lively conservation debates? Their repertoires of contention consisted of five different mechanisms. First, they made a written protest against the demolition. The key figures as well as the different organisations protested vigorously to the municipality, using five arguments. The entrance gates had to be preserved because they aroused memories of Antwerp's glorious past. The Emperor's Gate was inaugurated by Emperor Charles V in 1545 and the Kipdorp Gate contained a triumphal arch, erected on the occasion of Antwerp's victory over the duke of Alençon in 1583. The uniqueness of these entrance gates was a second argument. The Emperor's Gate was a prize example of sixteenth-century military architecture, the only one of its kind in Europe. The preservation group also emphasized the gates' artistic value. These monuments were prestigious and 
would beautify the new extended town of Antwerp. Building on this argument, they underlined the importance of the gates by referring to Edmond Fierlants' (1819-1869) assignment to photograph Antwerp buildings and monuments (1860). This photographer had included both the Emperor's and Kipdorp gate in his photo report, which indicated their importance. In 1865, on the initiative of the preservation group, Fierlants got an additional assignment to photograph the Kipdorp Gate. These photographs offer unique visual material of the demolition process [22] [Figure 3]. Finally the preservation group examined different examples of similar threats to monument preservation, like the entrance gates of Montpellier and Bordeaux. The group stated that although these gates obstructed city traffic and were enclosed by dwellings, they were preserved. They also cited the Brussels Halle Gate, the Antwerp Scaldis Gate and London's Temple Bar for the preservation campaign for these monuments had produced the desired results. This nourished their hope of a similar result for the threatened entrance gates.

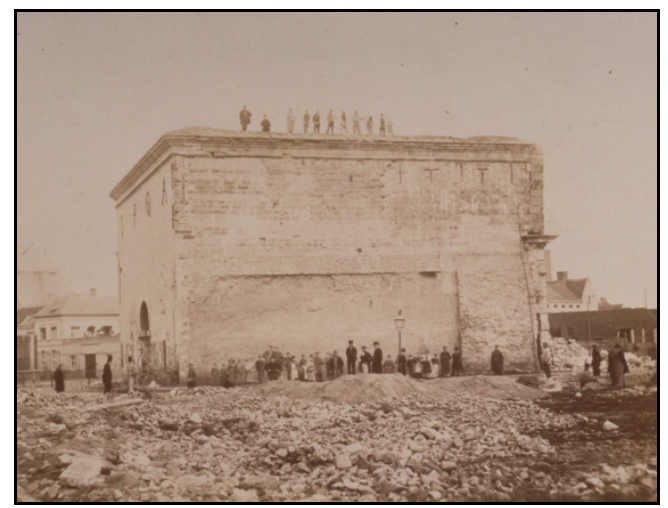

Figure 3: Demolition of the Kipdorp Gate, Edmond Fierlants, 1865.

A second mechanism, in order to make their objectives known to a wider audience, was Génard's publication of the Emperor's and Kipdorp Gate's history. With this intention in mind, the key figures also decided to discuss the preservation idea on the annual assembly of the Royal Commission for Monuments and their Provincial committees, on 18 and 19 January 1865. The preservation of the Antwerp gates was discussed and received the unanimous support of all participants. The initiative of the preservation group to offer the Antwerp municipality concrete propositions for preserving the gates in situ, can be seen as a fourth mechanism. They made small adaptations to the Van Bever plan, in order to preserve the gates and provide them of a big square. Furthermore, they worked out restoration propositions with the help of architect students of the Royal Commission for Monuments and proposed a new function such as archive or depot.

\subsubsection{Evaluation of the preservation campaign}

In order to exceed the traditional evaluation based on the life span and immediate successes of contentious politics groups, the reactions of the authorities and the 
public and the media attention they received, were taken into consideration. The Antwerp municipality waved aside the group's objections and countered their arguments. Firstly they endorsed the claim that the entrance gates aroused memories of Antwerp's past. In contrast with the preservation group, they however claimed these gates to be a reminder of Spanish oppression. The fortifications as a whole were generally referred to as the Spanish enceinte, even though properly speaking this adjective only applies to the citadel. This historic generalization, however, conveniently provided an additional pretext for the demolition [23]. Secondly, the importance of this military architecture was not acknowledged. City councillor Matthyssens for instance described the Emperor's Gate as 'a shapeless block of stone' [24]. Building on that, the artistic and monumental value of the gates was renounced. City councillor Van Spilbeeck disrespectfully said that 'some archaeologists won't throw away a piece of stone if they know it dates from the fifteenth or sixteenth century'. Furthermore, he stated that the gates had lost their monumental value when the city walls were demolished. Finally, the municipality emphasized they had reacquired ownership of the fortifications and entrance gates and thus 'could do what they want'. Although they acknowledged the importance of the Royal Commission for Monuments' advice, they underlined that this advice only applied for national buildings. Did the public support the preservation campaign? An indication that suggests the opposite is a petition in favour of the demolition of the Emperor's Gate, presented by 505 Antwerp inhabitant in September 1864. The Antwerp middle class was of course opposed to the preservation idea and agreed with the municipality on economic arguments in favour of the demolition. The preservation group realised that 'the public did not support the preservation idea' but thought that the Antwerp population might side with them if they knew 'which services such as archives or depots these buildings could bring the city' [25]. It is impossible to discover "the public's reactions" on the preservation campaign for the public was build-up of different sections of society, different professions, etc. It seems that especially the Antwerp middle class acted counter to the preservation group. The reactions of the other sections of society remain largely unknown. Finally the media attention received by the preservation group forms an indication of their success. This includes articles, interviews, etc. published in the periodicals of the participation groups as well as in the broader press. The mentions of the preservation group's objectives in De Vlaemsche School is a case in point of the first group. In 1864 and 1865 this periodical mentioned the preservation campaign, called for support, announced the publication of Génard's history of the city gates and finally reported their demolition [26]. The campaign also received media attention in the broader press. The article 'De stadspoorten' for example, was published in Het Handelsblad van Antwerpen on 15 January 1865 and largely used the same arguments as the Antwerp municipality in favour of the demolition. 


\section{Conclusion}

The community involvement with the nineteenth-century preservation campaign of the Antwerp fortifications is a complex ensemble of contentious politics. Pieter Génard, Henry Leys, François Durlet and Leo de Burbure - all members of the Antwerp Provincial Commission for Monuments - were the key figures of the preservation group. They can be conceived as pioneers due to their individual engagement in the preservation campaign. Their plea for the preservation of the Emperor's and the Kipdorp Gate gained support from the Royal Commission for Monuments and other architectural, artistic, and historical societies. The campaign never included the other entrance gates or the fortifications as a whole. It can be seen as a resolute attempt to preserve the two most monumental components of this military architectural patrimony. This proved a vain attempt as the municipality of Antwerp voted the demolition of the fortifications in 1865 . In order to exceed the traditional evaluation based on the life span and immediate successes of contentious politics groups, the reactions of the authorities and the public and the media attention they received, were also taken into consideration in this paper. The Antwerp municipality clearly acted counter to the preservation group and waved aside their arguments. The reaction of 'the public' is less univocal. It seems that especially the Antwerp middle class cut across the preservation group. The reactions of the other sections of society remain largely unknown. The media attention in the broader press shows another counteract against the preservation campaign. What is the conclusion on the movement's success? Even though not supported by the local municipality and the Antwerp middle class, the preservation campaign had a large scope of supporters within the Belgian cultural and archaeological circles. Although the material entrance gates were demolished, their iconographic preservation still remains because of the group's initiative. Not only did they plead for a material conservation, they also demanded an iconographic variant via the production of architectural designs and photographs. The ambiguous status that was connected with military architecture in the nineteenth century was maintained for a long time. Because of actions like the preservation campaign for the entrance gates, the architectural legacy was regularly brought to the notice of policymakers, cultural circles, the public, etc. This resulted in a growing interest in the preservation of military heritage all over Europe from 2005 onwards. The establishment of an International Scientific Committee on Fortifications and Military Heritage by ICOMOS in 2005 is a case in point. Contrary to their little immediate success, the preservation campaign achieved their objectives in the long term: more attention for and preservation of military heritage.

\section{References}

[1] ICOMOS, ICOFORT, http://icofort.icomos.org/home

[2] Bertels, I., Building the city, Antwerp 1819-1880, unpublished $\mathrm{PhD}$, KULeuven, 2008.; Lombaerde, P., (ed.), Antwerpen versterkt: de Spaanse omwalling vanaf haar bouw in 1542 tot haar afbraak in 1870, UPA, Brussels, 2009. 
[3] Bertels, I. \& Martens, P., Defunct Defenses: Antwerp's Sixteenth-Century Fortifications. Future Anterior, 3, pp.46-55, 2006.; I. Bertels, T. Bisschops \& B. Blondé, Stadslandschap. Ontwikkelingen en verwikkelingen van een stedelijke ruimte. (Chapter 1). Antwerpen. Biografie van een stad, ed. I. Bertels, B. De Munck \& H. Van Goethem, Meulenhoff/Manteau, Antwerp, pp.11-67, 2010.

[4] Stynen, H., De onvoltooid verleden tijd. Een geschiedenis van de monumenten- en landschapszorg in België 1835-1940, Stichting Vlaams Erfgoed, Brussel, 1998.

[5] Walgrave, S. \& Rihoux, B., De Witte Mars, een jaar later: van emotie tot politieke connotatie, Van Halewyck, Leuven, p.52, 1997.

[6] Dezeure, K., De Rynck, F., Steyvers, K. \& Reynaert, H., Factoren die burgerparticipatie in steden beïnvloeden. Internationaal vergelijkende literatuurstudie naar lokale participatie, Paper presented at the Politologenetmaal 2008, Berg en Dal, Holland, 29 and 30 May 2008.

[7] Mc Adam, D., Tarrow, S. \& Tilly, C., Dynamics of contention, Cambridge University Press, Cambridge, p. 23, 2001.

[8] Tarrow, S., Power in movement. Social movements and contentious politics, Cambridge University Press, Cambridge, p.75, 1998.

[9] Dezeure, K., De Rynck, F., Steyvers, K. \& Reynaert, H., Factoren die burgerparticipatie in steden beïvloeden, p.10.

[10] Walgrave, S. \& Rihoux, B., De Witte Mars, een jaar later, p.52.

[11] Lombaerde, P., (ed.), Antwerpen versterkt, p.24.

[12] I. Bertels, T. Bisschops \& B. Blondé, Stadslandschap, p.39.

[13] Bertels, I. \& Martens, P., Defunct Defenses, p. 50.

[14] Antwerp City, Bulletin communal 1864, 6 August 1864.

[15] Antwerp City, Bulletin communal 1864, 14 January 1864.

[16] Antwerp City, Bulletin communal 1864, 24 September 1864.

[17] Dobbels, J., Aanzetten voor een erfgoedbeleid. De afbraak van het Antwerpse burchtgebied als case-study voor de veranderende omgang met erfgoed (1863-1900)', Stadsgeschiedenis, 6(2), pp.129-145, 2011.

[18] Stynen, H., De onvoltooid verleden tijd, p.34.

[19] Anonymous, Notice bibliographique de Pierre Marius Nicolas Jean Génard, Hayez, Brussel, 1897.; Goovaerts, A., Alfons, Levensschets van ridder Leo de Burbure, toonzetter en geschiedschrijver, Fontaine, Antwerpen, 1871.; Marcellis, C., Henri Leys, dédié au Cercle artistique d'Anvers, Tarlier, Bruxelles, 1855.

[20] Antwerp City Archives, PK 3086, Letter of 23 December 1864.

[21] Antwerp City Archives, PK 3086, Letter of 19 January 1865.

[22] Van Goethem, H., Fotografie en realisme in de 19de eeuw. Antwerpen: de oudste foto's 1847-1880, Pandora, Antwerpen, pp.100, 224, 1999.

[23] Bertels, I. \& Martens, P., Defunct Defenses, p. 53.

[24] Antwerp City, Bulletin communal 1865, 3 June 1865.

[25] Antwerp City Archives, PK 3086, Letter of 26 August 1865.

[26] Several publications in the periodical De Vlaemsche school, 1864-1865. 